\title{
Effects of Analgesic Advertisements on Community in Hegarmanah Village, Jatinangor
}

Nurhayati binti Shaharuddin ${ }^{1}$, Eva M. Hidayat ${ }^{2}$, Jupiter Sibarani ${ }^{3}$

${ }^{1}$ Faculty of Medicine, Universitas Padjadjaran, ${ }^{2}$ Department of Pharmacology and Therapy, Faculty of Medicine, Universitas Padjadjaran, ${ }^{3}$ Department of Urology, Faculty of Medicine, Universitas Padjadjaran/ Dr. Hasan Sadikin General Hospital, Bandung

\begin{abstract}
Background: Currently, there are numerous analgesic advertisements which have been published in various media and have also attracted attention of the society. The aim of this study is to find out effects of analgesic advertisements on awareness and attention towards these advertisements on the community in Hegarmanah Village, Jatinangor.

Methods: The study used the descriptive method with participants consisting of community members in Hegarmanah Village who have seen, watched or heard about the analgesic advertisements and who were aged 18 years and above. The sample for this study consisted of 100 respondents. This study was conducted in September 2012-December 2012.

Results: The results showed that $82 \%$ of the respondents have seen the ads in at least the last 3 months and mostly watched them on television. About $52 \%$ of respondents agreed that many of the ads did not provide sufficient information. In addition, $50 \%$ only read a little bit of the ads rather than the whole advertisement. Fifty three percents of the respondents had the intention to try the medication after seeing the ads. More than $80 \%$ were aware about how to use the medication, medication's side effects, warnings and contraindications and $65 \%$ agreed that, they could make a better decision on their health condition after seeing the ads.

Conclusions: The analgesic advertisements indeed affected the community by making them aware about the ads and attracted them to buy as well as try the product itself. Further studies on factors which influence intake of over-the-counter analgesic drugs and also about the self-medication are required. [AMJ.2014;1(2):54-9]
\end{abstract}

Keywords: Analgesic advertisements, effects, society

\section{Pengaruh Iklan Analgesik terhadap Masyarakat di Desa Hegarmanah, Jatinangor}

\begin{abstract}
Abstrak
Latar Belakang: Saat ini, banyak iklan analgesik yang ditayangkan di beberapa media dan telah menarik perhatian masyarakat. Penelitian ini bertujuan untuk mengetahui pengaruh iklan analgesik terhadap kesadaran dan pemahaman mengenai obat analgesik pada masyarakat di Desa Hegarmanah, Jatinangor.

Metode: Penelitian ini menggunakan metode deskriptif dengan melibatkan partisipan yang terdiri dari anggota masyarakat di Desa Hegarmanah yang telah melihat, menyaksikan atau mendengar tentang iklan analgesik dan berusia 18 tahun ke atas. Sampel penelitian ini terdiri dari 100 responden. Penelitian ini dilakukan pada bulan September 2012-Desember 2012.

Hasil: Hasil penelitian menunjukkan bahwa $82 \%$ dari responden telah melihat iklan di setidaknya 3 bulan terakhir dan sebagian besar menonton di televisi. Sekitar 52\% dari responden setuju bahwa banyak dari iklan tidak memberikan informasi yang cukup. Selain itu, 50\% hanya membaca sedikit iklan daripada seluruh iklan. Lima puluh tiga persen dari responden memiliki niat untuk mencoba obat setelah melihat iklan. Lebih dari 80\% yang sadar tentang penggunakan, efek samping, peringatan dan kontraindikasi obat dan $65 \%$ setuju bahwa, mereka bisa membuat keputusan yang lebih baik tentang kondisi kesehatan mereka setelah melihat iklan.

Simpulan: Iklan analgesik memang memengaruhi masyarakat dengan membuat mereka paham tentang
\end{abstract}

Correspondence: Nurhayati binti Shaharuddin, Faculty of Medicine, Universitas Padjadjaran, Jalan Raya BandungSumedang Km.21, Jatinangor, Sumedang, Indonesia, Phone: +62 817020 5754, Email: sweety_atie@yahoo.com 
obat yang diiklankan dan menarik mereka untuk membeli serta mencoba produk tersebut. Penelitian lebih lanjut tentang faktor-faktor yang memengaruhi penggunaan obat analgesik yang dijual bebas dan juga tentang pengobatan sendiri masih diperlukan. [AMJ.2014;1(2):54-9]

Kata kunci: Iklan analgesik, efek, masyarakat

\section{Introduction}

Analgesic is a medication to eliminate pain.1 Currently, a lot of people consume over-thecounter 2 (OTC) drugs because it will reduce the number of visits to primary care offices and save money as it is cheaper than consulting the doctor. $^{2}$

Thus, a lot of consumers simply take this medication without reading or being aware of how the medication should be consumed. ${ }^{3}$ Many of them have inappropriate knowledge on how to take this medication and just consume the medication according to their knowledge which later can lead to serious problems. ${ }^{3}$ Every medication has its own side effects and contraindications and can cause harmful effects if taken without any attention to side effects, contraindications and dose. 3 The medication might not be effective and may even cause further suffering for the person who takes it. 3 The best way to treat this problem is by visiting the doctor to consult about the illness itself. ${ }^{3}$

Meanwhile, people are more likely to buy their own medication at the pharmacy rather than visiting the doctor because of the easy access and the lower price of the medication compared to consulting the doctor. ${ }^{3}$ The most common drugs that can be bought by the community is the OTC drugs which are usually advertised in various media, such as television, radio, magazine and internet. 3 The analgesic drugs that are usually advertised on television are medicine for headache, stomachache and others. ${ }^{4}$

In Indonesia there is a regulation on drug advertisements which should be obeyed by advertising companies. ${ }^{5}$ The function of this regulation is to make sure that the information delivered to the society is true and beneficial. 5 However, many pharmaceutical companies produce advertisements only to increase their profit rather than to give adequate information about their products, as not all information is written in the advertisement. ${ }^{6}$ Thus, these misleading advertisements consist of inadequate information regarding their products. $^{\text {? }}$
The Food and Drug Administration (FDA) of the United Stated has made a regulation to assure the safety, security and effectiveness of drugs advertisements to protect the society. 8 Indonesia also has its own authority who is responsible for the drugs advertisement regulation which is known as the Indonesia's National Agency for Drug and Food Control (NADFC). ${ }^{9}$ This authority protects the Indonesian public from counterfeit drugs and illegal products.9 For this reason, the NADFC has made a regulation in 2009 to protect society from unappropriate drugs promotion. ${ }^{10}$ Based on this regulation, it decided that every pharmaceutical company should get permission from the NADFC before releasing any promotion of its products. ${ }^{10}$

Therefore, this study on the effects of analgesic advertisements on the community in Hegarmanah Village, Jatinangor was conducted to asses the impacts of these ads to the society. The society's knowledge on the ads was also assessed to evaluate the correct understanding of what people saw, heard, or read in the ads. It is expected that this study would give a better understanding especially for the pharmaceutical companies in terms of better analgesic advertisements and to create awareness among the society members regarding the information given and to follow the instruction.

\section{Methods}

This community survey used a self-conducted questionnaire as the instrument. This questionnaire is divided into two categories, respondent's characteristics and questions regarding analgesic advertisements. The characteristic part includes questions on name, age, gender, address, occupation, last education, monthly salary, and ethnicity. Concerning the analgesic advertisements, 15 questions were required to be answered by the respondents.

This study used the descriptive method and was conducted from September 2012 to December 2012. The populations for the study were the people of Hegarmanah Village, 
Jatinangor. The total population was calculated by using the Slovin formula:

Based on the calculation above, the total population covered 100 respondents. The inclusion criteria for this study were people who have already seen or heard the advertisements about the analgesic

$$
\begin{aligned}
& \mathrm{n} \approx \frac{\mathrm{N}}{1+\mathrm{Ne}^{2}} \\
& \mathrm{n} \approx \frac{7758}{1+(7758)(0.1)^{2}} \\
& \mathrm{n} \approx \frac{7758}{1+(77.58)} \\
& \mathrm{n} \approx \frac{7758}{78.58} \\
& \mathrm{n} \approx 98.73 \\
& \mathrm{n} \approx 100 \text { respondents }
\end{aligned}
$$

Note:

$\mathrm{n}=$ number of respondents

$\mathrm{N}=$ population sample

$\mathrm{e}=$ error tolerance $(10 \%)$

and who were 18 years and older. The respondents were selected randomly in Hegarmanah Village. The exclusion criterion was incomplete questionnaires. Validation and reliability tests were performed to 30 respondents and the results show that it was a valid and reliable questionnaire $(>0.700)$. Data were analyzed using descriptive analysis to find the percentage for each question in the questionnaire.

\section{Results}

The majority of the people who responded to this questionnaires were female $(60 \%)$ around 18 to 27 years old (32\%), housewife (29\%) with low education status (42\%), had a monthly income of more than $\mathrm{Rp} 1,000,000$ $(28.1 \%)$ and were Sundanese $(66 \%)$ (Table $1)$.

\section{Discussion}

In the last three months, $82 \%$ of the respondents were aware of the existence of the analgesic advertisements and which they mostly watched on television. This showed that, there were a lot of analgesic advertisements which have been published or broadcasted that have captured the attention of the society.This might be caused by the fact that the advertisements were attractive and some of them even used popular celebrities to promote the drug.

Every advertisement should include all information required by the authority. However, there were still numerous companies which did not provide sufficient information as $52 \%$ agreed that information in the advertisements was not enough. Society stated that, some of the information were written in small fonts and located at the bottom part of advertisement which made it difficult to read.

Half of the respondents only read a small part of the advertisement because they considered the duration of the advertisement on television too short and did not provide

\begin{tabular}{|c|c|c|}
\hline Variables & Total & $\begin{array}{l}\text { Percentage } \\
(\%)\end{array}$ \\
\hline \multicolumn{3}{|l|}{ Gender } \\
\hline Female & 60 & 60 \\
\hline Male & 40 & 40 \\
\hline \multicolumn{3}{|l|}{ Age } \\
\hline $18-27$ & 50 & 50 \\
\hline $28-37$ & 23 & 23 \\
\hline $38-47$ & 19 & 19 \\
\hline $48-57$ & 5 & 5 \\
\hline $58-67$ & 3 & 3 \\
\hline \multicolumn{3}{|l|}{ Occupations } \\
\hline Housewife & 29 & 29 \\
\hline Government employee & 0 & 0 \\
\hline Private employee & 9 & 9 \\
\hline Farmer & 5 & 5 \\
\hline Student & 12 & 12 \\
\hline Entrepreneur & 27 & 27 \\
\hline Others & 18 & 18 \\
\hline \multicolumn{3}{|l|}{ Education } \\
\hline Primary school & 11 & 11 \\
\hline Junior high school & 25 & 25 \\
\hline Senior high school & 42 & 42 \\
\hline University & 22 & 22 \\
\hline \multicolumn{3}{|l|}{ Income } \\
\hline$<250,00$ & 9 & 14.1 \\
\hline $255,000-500,000$ & 8 & 12.5 \\
\hline $505,000-750,000$ & 16 & 25.0 \\
\hline $755,000-1,000,000$ & 13 & 20.3 \\
\hline$>1,000,000$ & 18 & 28.1 \\
\hline \multicolumn{3}{|l|}{ Ethnicity } \\
\hline Sunda & 66 & 66 \\
\hline Jawa & 8 & 8 \\
\hline Batak & 1 & 1 \\
\hline Others & 25 & 25 \\
\hline
\end{tabular}
enough time to read the complete information. Besides, some of them stated that they did not feel like reading the ads and only saw it once.

\section{Table 1 Respondent Characteristic} Distribution 
Table 2 Effects of Analgesic Advertisements on Community Distribution

\begin{tabular}{lcc}
\hline \multicolumn{1}{c}{ Variables } & Yes (\%) & No (\%) \\
\hline Awareness on analgesic advertisements & 82 & 18 \\
Complete information stated in analgesic advertisement & 48 & 52 \\
Intention to find more information about analgesic advertisements & 61 & 39 \\
Intention to try the drugs after seeing the advertisements & 53 & 47 \\
Improvement of symptom as shown in the advertisements & 77 & 23 \\
Intention towards warning, side effect and contraindication & 87 & 13 \\
Understand how to use the drugs & 83 & 11 \\
Dosage intake according to instructions & 89 & 65 \\
Effects of analgesic advertisements on society health & & 35 \\
\hline
\end{tabular}

Although OTC analgesic medications can easily be purchased from various types of places such as pharmacies, supermarket and drug stores, many of them preferred the pharmacy because they were more confident in the pharmacy rather than a mere shop as it was more reliable and clean. However, $36 \%$ more preferred to buy the medication from the grocery shop as the shop was nearby their house and also the prices were cheaper than buying the medication at the pharmacy or consulting the doctor.

About $61 \%$ of respondents had intention to find more information on analgesic advertisements which they have seen or heard. Most of them would find it on the internet as the internet was the easiest way to find information. The respondents also used the alternative way like asking the family or neighbor who knew about the drugs or find it out from magazines or books.

The analgesic advertisement gave effect towards the society because as they watch the advertisement, it made them want to buy and try the medication especially when they had the similar symptom as shown in the advertisement. They stated that the advertisements were attractive and triggered them to try it, however $47 \%$ stated that they did not feel like trying it even though the ads were attractive. They only bought the medicine if there was any complaint or just consulted the doctor rather than simply buy the medicine.

Most of the respondents were satisfied with the medicine as the effect was similar to what was promoted in the advertisements. Only $23 \%$ did not get the effect that they really wanted when they used the medication.

More than $80 \%$ were aware about the warning, side effects, contraindication, dosage intake and how to use the medication. They stated that they read first the instructions which were usually written at the back of the box before the intake of the medication. However, there were still respondents who did not understand the instructions because some of them could not read and did not bother to ask other people about the instructions. To make it worse, since there was no improvement, they would simply take the medication beyond the instruction. Meaning, they would take the dosage more than was instructed.

More than half of the respondents took a good initiative to discontinue taking the drugs if there was a sign of side effect that occur to them. According to the respondents, they would stop immediately when they noticed a side effect. There were $37 \%$ who would consult the doctor about the problem because they believed that the doctor could help them to cure the side effect. However, there were still some respondents (4\%) who were not concerned and just let it be as according to them it was only a small matter and did not cause any harm to them.

Besides $63 \%$ felt that by seeing or hearing the analgesic advertisements could help them to make a better decision about their health status because some of them stated that their problem might be similar to those shown in the advertisements

However, another 35\% did not have any confidence that just by seeing the advertisements could help them made the right decision regarding their health. They also mentioned that their health could only be confirmed by the doctor as the doctor has more understanding about the illness.

In conclusion, the analgesic advertisements give effects toward the community by making 
Table 3 Effects of Analgesic Advertisements on Community Distribution

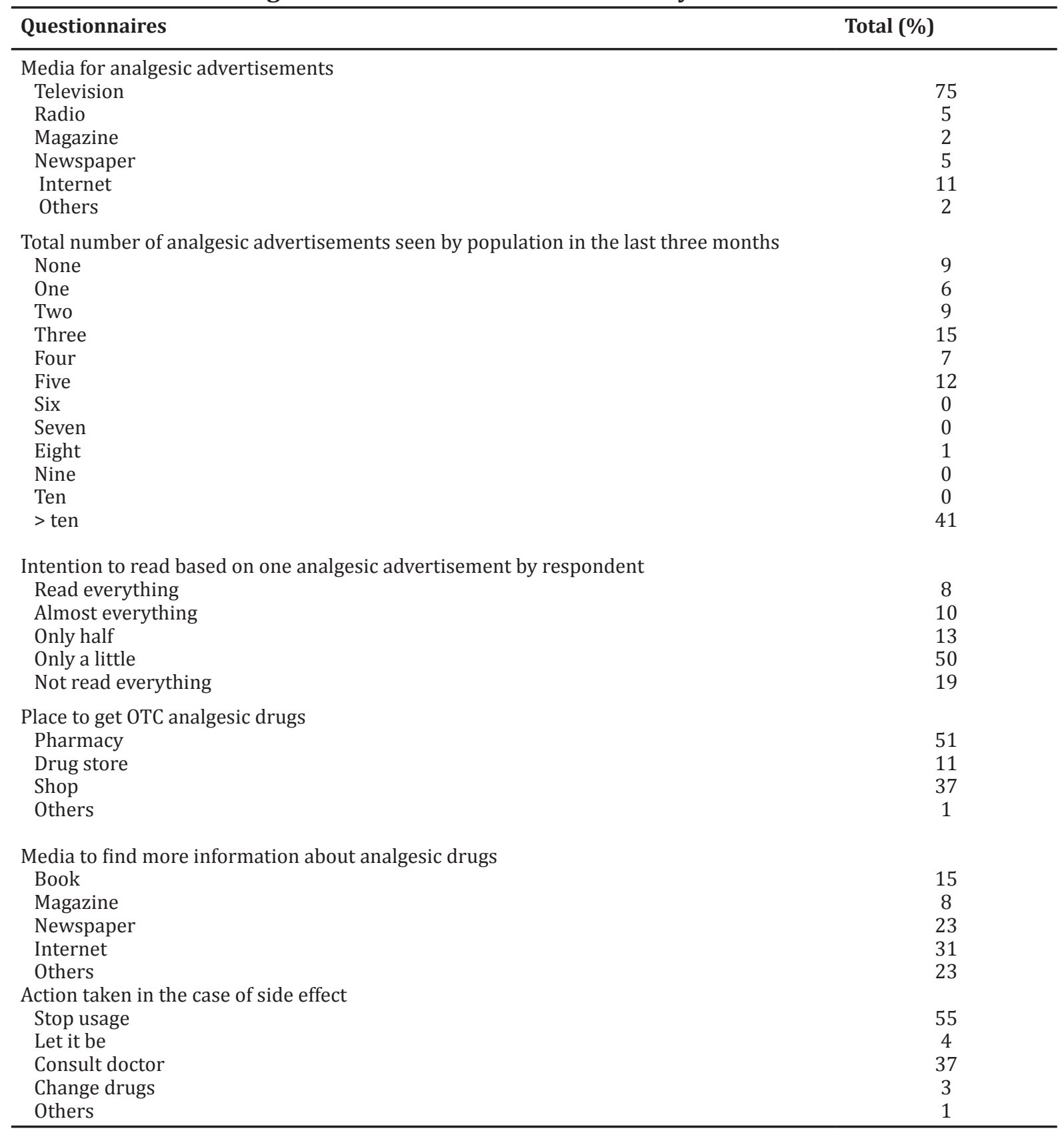

them aware about the ads and also attract them to buy as well as try the medication itself. Others can make further studies on the factors which influence intake of over-the-counter analgesic drugs and the self-medication.

\section{References}

1. Dorland. Dorland's illustrated medical dictionary: analgesic. 32th ed. Philadephia:
Elsevier Saunders; 2011. p. 71.

2. London PA, Shostak D. Potential reduction in unnecessary visits to doctors from safe and appropriate use of OTC medicines could save consumers and taxpayer billions annually. Washingon DC: The Your Health at Hand; 2011 [cited 2012 July 13]. Available from. http://www. yourhealthathand.org/images/uploads/ London_Cost_Saving_Study_061711.pdf

3. Ary. Jangan sembarangan beli obat 
warung. Jakarta: 108Jakarta.com; 2012 [cited 2012 July 13]. Available from: http://www.108jakarta.com/ jakarta/2012/07/13/1862/JanganSembarangan-\%20Beli-Obat-Warungan.

4. Kimin A. Paracetamol: komponen obat flu paling popular. Tangerang: Apotekputer. com; 2012 [cited 2012 June 10]. Available from: http://apotekputer.com/ma/index. php?option=com_content\&task=view\&id= 50\&Itemid=1.

5. Supardi S, Handayani RS, Herman MJ, Raharni, Susyanty AL. Kebijakan periklanan obat dan obat tradisional di Indonesia. Bul. Penel. Sistem Kes. 2011;14(1):59-67

6. Greene JA, Choudhry NK, Kesselheim AS, Brennan TA, Shrank W. Changes in directto-consumer pharmaceutical advertising following shifts from prescriptiononly to over-the counter status. JAMA. 2012;308(10):973-5.
7. Turisno BE. Perlindungan konsumen dalam iklan obat. Masalah-Masalah Hukum. 2012;41(1):9.

8. Huh J, DeLorme DE, Reid LN, An S. Direct-toconsumer prescription drug advertising. Minneapolis: Minnesota Medicine; 2010 [cited 2012 June 10]. Available from: http://www.minnesotamedicine. com/Past-Issues / Past-Issues-2010/ March-2010/Clinical-Jisu-March-2010.

9. Gross A. Indonesia pharmaceutical update 2012. Bethesda: Pasific Bridge Medical Publication; 2012 [cited 2012 June 10]. Available from: http://www. pacificbridgemedical.com/publications/ indonesia-pharmaceutical-update-2012/.

10. Supardi S. Kajian Peraturan PerundangUndangan Tentang Iklan Obat dan Peran Serta Masyarakat dalam Pengawasannya. Jur Kefarmasian Indo. 2009;1(3):112-20. 